\title{
Mold Species in Dust from the International Space Station Identified and Quantified by
}

\section{Mold Specific Quantitative PCR}

Stephen J. Vesper ${ }^{\mathrm{a} *}$, Wing Wong ${ }^{\mathrm{b}}$ C. Mike Kuo ${ }^{\mathrm{c}}$, Duane L. Pierson ${ }^{\mathrm{d}}$

a National Exposure Research Laboratory (NERL), United States (US) Environmental Protection Agency, Cincinnati, OH;

${ }^{\mathrm{b}}$ Enterprise Advisory Services Inc., Houston, TX

c WYLE Laboratories Inc., Houston, TX

d Johnson Space Center, National Aeronautics and Space Administration, Houston, TX

*Corresponding Author: Stephen Vesper, US EPA, 26 West M.L. King Ave., M.L. 314,

Cincinnati, Ohio 45268. Phone: 513-569-7367; email: vesper.stephen@epa.gov

\begin{abstract}
Dust was collected over a period of several weeks in 2007 from various HEPA filters in the U.S. Laboratory Module of the International Space Station (ISS). The dust was returned on the Space Shuttle Atlantis, mixed, sieved, and the DNA was extracted. Using a DNA-based method called mold specific quantitative PCR (MSQPCR), 39 molds were measured in the dust.

Opportunistic pathogens Aspergillus flavus and A. niger and toxin producers Penicillium

chrysogenum and P. brevicompactum were found at relatively high concentrations (compared to U.S. homes). No cells of the opportunistic pathogens A. fumigatus, A. terreus, Fusarium solani or Candida albicans were detected.
\end{abstract}

Keywords: International Space Station, mold specific quantitative PCR, Aspergillus 


\section{Introduction}

Since human space exploration began, microbes have traveled with us and are ubiquitous throughout the spacecraft. Previous studies have demonstrated that bacteria, including potential pathogens, were commonly isolated in the air, water, and on surfaces aboard the Mir Space Station [12] and the International Space Station (ISS) [1,6]. Biofilms were found in the water distribution lines on the Space Shuttle Discovery [5].

Another important group of microbes are the fungi or molds. Molds like Penicillium chrsogenum were measured on the Mir Space Station from the beginning of its on-orbit service [18]. Six "space fungi” including P. chrysogenum and Aspergillus versicolor were identified by morphology and sequence analysis and were shown to be amplifying on the Mir [7]. A six year survey of the ISS showed the concentration of molds ranged from a high of less than $4.4 \times 10^{1}$ $\mathrm{CFU} / \mathrm{m}^{3}$ air to $4.3 \times 10^{4} \mathrm{CFU}$ per $100 \mathrm{~cm}^{2}$ of surfaces [11]. However, these analyses were all based on culturing the molds. It is important that timely information about the concentration of molds in the ISS is available, since molds present a threat to the integrity of the health of the cosmonauts/astronauts manning the ISS and the components of the ISS itself [11].

Potential health threats from molds include infections, toxicity and allergic reactions such as asthma. Although most molds are not a threat to humans with a healthy immune system, numerous studies have shown that the immune system of many astronauts were affected as a result of space flight and habitation $[3,4,8,9,13,15,16]$. Most parameters of the immune system were altered, usually decreased, resulting from various factors associated with space flight. Although no known mold health effects have occurred among the astronauts as a result of their time aboard the ISS, monitoring of these mold species is important for evaluating the threat. 
Mold growth is also potentially problematic for the integrity and operation of the ISS itself. Molds are saprophytic and therefore, to grow and multiply, they must breakdown organic substrates, which could be parts of the ISS.

In this study, a rapid (<2 hour), DNA-based method of mold analysis called mold specific quantitative PCR (MSQPCR) was used to identify and quantify mold species found in the dust collected aboard the ISS. The focus was the 36 species common to environments on earth, as described by the Environmental Relative Moldiness Index (ERMI) [17], and three additional opportunistic pathogens.

\section{Materials and methods}

A vacuum bag dust sample was collected from various HEPA filters in the U.S. Laboratory module of the ISS. Vacuuming of the HEPA filters is a part of the nominal housekeeping activities on-board the ISS. The dust was returned on the Space Shuttle Atlantis in 2007. The dust was thoroughly mixed and then sieved through a 300 micron pore size nylon mesh (Gilson Company, Inc. Lewis Center, OH). The DNA was extracted and purified from the samples using the GeneRite DNA-EZ ${ }^{\mathrm{TM}}$ kit, as directed (KC101-04C-50; GeneRite, Kendal Park, NJ). Replicate analyses of $5.0 \pm 0.1 \mathrm{mg}$ dust from the sample were performed [17]. All primer and probe sequences, as well as known species comprising any assay cluster were published at the EPA website: http://www.epa.gov/microbes/moldtech.htm.

\section{Results and discussion}

The results of the MSQPCR analysis of the dust from the ISS are shown in Table 1. The most common species measured was $P$. chrysogenum (average 350 cell equivalents per mg dust) 
followed by Aureobasidium pullulans (average 96 cell equivalents per mg dust). Of the 36 species in the standard ERMI analysis, 17 were detected at some concentration. Three additional opportunistic pathogens, A. terreus, Fusarium solani, and Candida albicans, were not detected in the dust (data not given).

Common species causing aspergillosis that were detected included, A. flavus and A. niger (average 27 and 92 cell equivalents per mg dust, respectively). Additional, occasional pathogens and toxin producing species measured on the ISS were $P$. brevicompactum and A. sydowii (average 32 and 16 cell equivalents per mg dust, respectively). Stachybotrys chartarum was not detected in the ISS dust.

Historically, the ISS environment was monitored by both the U.S. and the Russians in their respective modules by periodically collecting samples from the air and various surfaces [12]. The air and surface samples collected by astronauts in the U.S. segment were incubated on-board the ISS and colony counts recorded by the crew. This approach gave the crew an estimate of the number of viable microbes relatively quickly (depending on microbial growth rate). However, for identification of the microbes, the cultures were returned to earth. Typically Russian cosmonauts collected air samples and the crew recorded the number of bacterial and mold colonies after incubation [10]. However, surfaces samples were collected and stabilized for return to earth, where the microbes were cultured, identified and quantified.

Novikova et al. [11] described two fundamental limitations in these methods used to monitor microorganisms on the ISS: the time gap between sampling and results and the reliance on culture-based analyses. The DNA-based method applied in this study can solve both of these problems. 
Although, in this case, the dust sample was returned to earth for analysis, a number of companies are developing instrumentation that would make this analysis available on a nearly real-time basis and could potentially be performed on the ISS. In addition, this DNA-based analysis eliminates the need for culturing and is already available for more than 100 common molds (http://www.epa.gov/microbes/moldtech.htm.). The results are specific, quantitative and available in about 2 hours. In most cases, the MSQPCR assays are sensitive down to a single cell [2].

This ISS dust sample contained the opportunistic pathogens A. flavus and A. niger at concentrations higher than the geometric mean measured in homes across the U.S. [17]. Just as important, the tests demonstrated that other opportunistic pathogens including, A. fumigatus, $A$. terreus, F. solani and C. albicans were not present (at least at this time and in this sample).

In addition to infections, many molds produce mycotoxins which can affect the immune system and other organs. For example A. flavus is the source of aflatoxin, a known carcinogen. Other molds quantified by MSQPCR on the ISS included $P$. chrysogenum and $P$. brevicompactum which produce toxins that can cause inflammatory and cytotoxic responses [14]. Both of these molds were found at relatively high concentrations aboard the ISS, compared to a typical U.S. home [17].

\section{Conclusions and Perspective}

It is important to emphasize that there have been no known mold infections or other health effects from molds as a result of living aboard the ISS. Of course, this is just one sample and many more samples would be needed to fully describe the mold conditions of the ISS. Novikova 
et al., [11] opined "Continuous environmental monitoring during the lifetime of the ISS is of paramount importance.” The use of MSQPCR may be one method to reach this goal.

\section{Acknowledgements}

We wish to thank Expedition 16 mission specialists for collecting the dust sample. Also, we wish to thank NASA Johnson Space Center Toxicology group members John James, Noreen Khan, and John Boyd for their technical assistance.

\section{Notice}

The U.S. Environmental Protection Agency (EPA) through its Office of Research and Development collaborated in the research described here. It has been subjected to the Agency’s peer review and has been approved as an EPA publication. Mention of trade names or commercial products, including those that embody EPA patented technology, does not constitute endorsement or recommendation by the EPA for use.

\section{References}

[1] V.A. Castro, A.N. Thrasher, M. Healy, C.M. Ott, D.L. Pierson. Microbial characterization during the early habitation of the International Space Station. Microb Ecol. 47 (2004) 11926.

[2] R.A. Haugland, M.Varma, L.J. Wymer, S.J. Vesper. Quantitative PCR of Selected Aspergillus, Penicillium and Paecilomyces Species. Syst. Appl.Microbiol. 27 (2004) 198210.

[3] I. Kaur, E.R. Simons, V.A. Castro, C.M. Ott, D.L. Pierson. Changes in neutrophilfunctions in astronauts. Brain Behav. Immun. 18 (2004) 443-50. 
[4] I. Kaur, E.R. Simons, V.A. Castro, C.M. Ott, D.L. Pierson. Changes in monocytefunctions of astronauts. Brain Behav. Immun. 19 (2005) 547-54.

[5] D.W. Koenig, D.L. Pierson. Microbiology of the Space Shuttle water system. Water Sci Technol. 35 (1997) 59-64.

[6] M.T. La Duc, R. Sumner, D. Pierson, P. Venkat, K Venkateswaran. Evidence of pathogenic microbes in the International Space Station drinking water: reason for concern? Habitation (Elmsford). 10 (2004) 39-48.

[7] K. Makimura, R. Hanazawa, K. Takatori, Y. Tamura, R. Fujisaki, Y. Nishiyama, S. Abe, K. Uchida, Y. Kawamura, T. Ezaki, H. Yamaguchi. Fungal flora on board the Mir-Space Station, identification by morphological features and ribosomal DNA sequences. Immunol. 45 (2001) 357-63.

[8] S.K. Mehta, I. Kaur, E.A. Grimm, C. Smid, D.L. Feeback, D.L. Pierson. Decreased nonMHC-restricted (CD56+) killer cell cytotoxicity after spaceflight. J Appl. Physiol. 91 (2001) 1814-8.

[9] S.K. Mehta, R.J. Cohrs, B. Forghani, G. Zerbe, D.H. Gilden, D.L. Pierson. Stress-induced subclinical reactivation of varicella zoster virus in astronauts. J. Med. Virol. 72 (2004) $174-9$.

[10] N.D. Novikova. Review of the knowledge of microbial contamination of the Russian manned spacecraft. Microb. Ecol. 47 (2004) 127-32.

[11] N. Novikova, P. De Boever, S. Poddubko, E. Deshevaya, N. Polikarpov, N. Rakova, I. Coninx, M. Mergeay. Survey of environmental biocontamination on board the International Space Station. Res. Microbiol. 157 (2006) 5-12. 
[12] C.M. Ott, R.J. Bruce, D.L. Pierson. Microbial characterization of free floating condensate aboard the Mir space station. Microb. Ecol. 47 (2004) 133-6.

[13] D.L. Pierson, R.P. Stowe, T.M. Phillips, D.J. Lugg, S.K. Mehta. Epstein-Barr virus shedding by astronauts during space flight. Brain Behav. Immun. 19 (2005) 235-42.

[14] T.G. Rand, S. Giles, J. Flemming, J.D. Miller, E. Puniani. Inflammatory and cytotoxic responses in mouse lungs exposed to purified toxins from building isolated Penicillium brevicompactum Dierckx and P. chrysogenum Thom. Toxicol. Sci. 87 (2005) 213-22.

[15] R.P. Stowe, S.K. Mehta, A.A. Ferrando, D. L. Feeback, D.L. Pierson. Immune responses and latent herpesvirus reactivation in spaceflight. Aviat. Space Environ. Med. 72 (2001) 884-91.

[16] R.P. Stowe, C.F. Sams, D.L. Pierson. Effects of mission duration on neuroimmune responses in astronauts. Aviat. Space Environ. Med. 74 (2003) 1281-4.

[17] S.J. Vesper, C. McKinstry, R.A. Haugland, L. Wymer, P. Ashley, D. Cox, G. Dewalt, W. Friedman. Development of an environmental relative moldiness index for homes in the U.S. J. Occup. Environ. Med. 49 (2007) 987-90.

[18] A.N. Viktorov, N.D. Novikova, E.A. Deshevaia, M.P. Bragina, A.V. Shnyreva, T.P. Sizova, I.T. D'iakov. Residential colonization of orbital complex "Mir" environment by Penicillium chrysogenum and problem of ecological safety in long-term space flight. Aviakosm. Ekolog. Med. 32 (1998) 57-62. 
Table 1. Mean and standard deviation (STD) of the replicate analyses of the concentration of each mold species expressed as cell equivalents (CE) per mg in vacuum bag dust from International Space Station. $\mathrm{ND}=$ not detected. NA = not applicable.

\begin{tabular}{|c|c|c|}
\hline & Mean & STD \\
\hline Mold Species & CE./mg & CE./mg \\
\hline \multicolumn{3}{|l|}{ Group 1} \\
\hline Aspergillus flavus & 27 & 6 \\
\hline Aspergillus fumigatus & ND & NA \\
\hline Aspergillus niger & 92 & 68 \\
\hline Aspergillus ochraceus & ND & NA \\
\hline Aspergillus penicillioides & 3 & 2 \\
\hline Aspergillus restrictus & ND & NA \\
\hline Aspergillus sclerotiorum & ND & NA \\
\hline Aspergillus sydowii & 17 & 19 \\
\hline Aspergillus unquis & ND & NA \\
\hline Aspergillus versicolor & ND & NA \\
\hline Aureobasidium pullulans & 96 & 120 \\
\hline Chaetomium globosum & 3 & 2 \\
\hline Cladosporium sphaerospermum & 1 & 0.7 \\
\hline Eurotium Group & 8.0 & 6 \\
\hline Paecilomyces variotii & ND & NA \\
\hline Penicillium brevicompactum & 32 & 18 \\
\hline Penicillium corylophilum & 4 & 3 \\
\hline Penicillium crustosum Group & 10 & 7 \\
\hline Penicillium purpurogenum & 3 & 2 \\
\hline Penicillium spinulosum & ND & NA \\
\hline Penicillium variabile & ND & NA \\
\hline Scopulariopsis brevicaulis & 1 & 0.7 \\
\hline Scopulariopsis chartarum & ND & NA \\
\hline Stachybotrys chartarum & ND & NA \\
\hline Trichoderma viride & ND & NA \\
\hline Wallemia sebi & 3 & 2 \\
\hline \multicolumn{3}{|l|}{ Group 2} \\
\hline Acremonium strictum & ND & NA \\
\hline Alternaria alternata & 4 & 2 \\
\hline Aspergillus ustus & ND & NA \\
\hline
\end{tabular}




\begin{tabular}{|l|r|r|} 
Cladosporium cladosporioides 1 & 17 & 4 \\
\hline Cladosporium cladosporioides 2 & ND & NA \\
\hline Cladosporium herbarum & ND & NA \\
\hline Epicoccum nigrum & ND & NA \\
\hline Mucor Group & ND & NA \\
\hline Penicillium chrysogenum 2 & 350 & 156 \\
\hline Rhizopus stolonifer & ND & NA \\
\hline & & \\
\hline & & \\
\hline
\end{tabular}

